\title{
Aspects of the Reproductive Biology of Black-Striped Pipefish Syngnathus abaster Risso, 1827 (Actinopterygii: Syngnathidae) in the Zaporizke Reservoir, Ukraine
}

\author{
Oleh Marenkov \\ Oles Honchar Dnipro National University, Ukraine \\ Research Institute of Biology, Research Laboratory of Hydrobiology, Ichthyology and Radiobiology \\ P.M.B. 49050, Dnipro, Ukraine \\ Corresponding Email: gidrobions@gmail.com
}

Keywords: Black-striped pipefish, Syngnathus abaster, Zaporizke Reservoir, fecundity, oocytes, embryos.

\begin{abstract}
Black-striped pipefish Syngnathus abaster Risso, 1827 (Actinopterygii: Syngnathidae) has successfully spread in freshwater ecosystems of Ponto-Caspian basin. Monitoring studies show a steady increase in the number and biomass of pipefish in waters of Dnipro region. It is highly adaptable and breeds in a fresh water. This fact indicates the physiological plasticity of the reproductive system and ability to adapt to new environmental conditions. In the Zaporizke Reservoir pipefish spawns at a temperature of $18.0-22.0^{\circ} \mathrm{C}$ in the coastal area of the reservoir. Pipefish with a body length of 8.9 to $12.5 \mathrm{~cm}$ had gonads with weight of about $0.13 \mathrm{~g}$, and the number of eggs ranged from 26 to 68 . The maximum fertility had female $155 \mathrm{~mm}$ long and it reached 69 eggs. Size of eggs reached about $1.2 \pm 0.05 \mathrm{~mm}$. The histological analysis of the gonads of pipefish and research of histometric measurements of eggs of fish at various stages of development was first conducted. In the period before pipefish spawning, there were eggs in different stages of maturity in the ovaries: oocyte in the phase of primary follicle «C», oocyte in the phase of vacuolation $\left\langle\mathrm{D}_{3}\right\rangle$, oocyte in the phase of trophoplasmatic growth «E», beginning phase of mature follicle $\langle\mathrm{F}\rangle$. Research of pipefish reproduction has important theoretical and practical significance for resolving issues with the spread of this species and its adaptation to new conditions.
\end{abstract}

\section{Introduction}

Black-striped pipefish Syngnathus abaster Risso, 1827 is the euryhaline fish species, able to tolerate significant variations in salinity, and thus lives in both fresh and salt water [1]. Representatives of the species are common in the eastern Atlantic from southern part of Biscay Bay to Gibraltar, in the Mediterranean, Black, Azov and Caspian seas [2-5].

Factor of global warming simultaneously with creating overregulated river water flow that led to the transformation of major rivers into the chain of reservoirsis the direct cause and the basis of biological invasions of fish into the basins of biggest rivers of Ponto-Caspian flow in the current period [6-8]. As an alien species it is found in the fresh waters of the Black Sea, Azov Sea and Caspian Sea basins [1]. In the Danube basin it goes up to the border of Romania and Hungary. In Ukraine, it is found along all coasts [9]. In the north-western and north-eastern parts of the Azov Sea these are Siwash Lake, Utlyutskyy and Molochniy estuaries, mouth and lower reaches of the Berda, Obticna and further east to the Don, and in the Kerch Strait. It is found along the coast of the Black Sea, Crimea, Dnipro-Bug estuary, Berezanskii strait and Dniester River. It inhabits Danubian lakes such as Cahul, Yalpug and also the Kakhovka Reservoir [3, 9]. In the Dnipro River it is found up to Kyiv [3].

Earlier in Ukraine this species was met just in the lower reaches of the Dnipro, Black and Azov seas, but after regulation of the Dnipro River and creating a cascade of reservoirs pipefish has become the typical inhabitant of the Dnipro reservoirs. Today pipefish is widespread and numerical species in the Zaporizke Reservoir [1]. It is found throughout the coastal area of the reservoir and its tributaries. This species is competitor for young commercial species and plankton-eater fish [8]. 
Long-term monitoring studies indicate a steady increase in the number and biomass of pipefish in waters of Dnipro region [1,3]. It is determined that it is well adapted and breeds under conditions of anthropogenic load of fresh water, which indicates the physiological plasticity of the reproductive system and ability to adapt to new environmental conditions.

Until now, there were no comprehensive research work on the ecology and biology of the black-stripe pipefish under conditions of the Zaporizke Reservoir [10]. Also, researchers report that reproduction of pipefish in fresh waters of Ukraine are not investigated $[3,9]$.

In this context, the aim of our work was studying the functioning of the reproductive system of pipefish in the Zaporizke Reservoir.

\section{Materials and Methods}

Researches were conducted in the Zaporizke Reservoir (is located in the South-west of Ukraine) during 2013-2016. The object of the research was the black-striped pipefish Syngnathus abaster Risso, 1827. Fish were caught from $10^{\text {th }}$ of May till $10^{\text {th }}$ of September in shallow water areas (at depths ranging from $10 \mathrm{~cm}$ to $1.5 \mathrm{~m}$ ). Fishing gear was beach seine (length of $25 \mathrm{~m}$, height of $1.5 \mathrm{~m}, 0.5 \mathrm{~mm}$ mesh size) and ten meter long nylon minnow seine with mesh size of $4 \mathrm{~mm}$. Biological analysis was carried out per conventional ichthyological classical methods [11]. Caught pipefish were fixes by $4 \%$ formalin solution for the preservation and further research. Totally, 260 specimens of black-striped pipefish were used for full biological analysis, 109 samples of eggs were collected and analyzed to determine the fertility, 50 histological slices of fish eggs were manufactured and analyzed, 420 specimens of free embryos were collected and analyzed.

For studying the reproductive capacity and reproduction features of pipefish, ovaries in different stages of maturity were taken from females, which was determined visually and histologically. Samples of gonads were fixed in a solution of Buena $(15 \mathrm{ml}$ of picric acid, $5 \mathrm{ml}$ of $40 \%$ formalin, $1 \mathrm{ml}$ of glacial acetic acid) and treated per conventional histological methods [12] in the following sequence: washing and dewatering fixed material; pouring in paraffin; cutting on microtome. Histological sections of small fish were made using whole animal.

Sections of gonads were dyed using hematoxylin-eosin and by Mallory [13]. Sledge microtome MS-2 was used for making sections. Photos of histological preparations were made with a digital camera «Sciencelab T500 5.17M», which was connected to microscopes «Jenaval», «Biolam $70 »$ or the binocular. In oocytes it were measured square of cross-section, diameter and thickness of egg cell membranes.

The experiment was performed according to the Provisions for the use of animals in biomedical experiments and permission of local ethical committee of Oles Honchar Dnipro National University.

The statistical analysis of the results was conducted in Statistica 8.0 (StatSoft Inc., USA). The differences between the selections were found using one-way ANOVA and considered significant at $\mathrm{P}<0.05$. All results are presented as the means \pm standard deviation (SD).

\section{Results}

The study of development of pipefish gonads using histological methods allows understanding the processes occurring in the gonads of alien fish under the new conditions of existence. The change in environmental conditions, such as life in fresh water should also affect the functioning of the reproductive system of fish. Also, as a result of migration of pipefish from south to north there are changes in the timing of spawning, caused by a new climatic conditions and the impact of global warming.

Since pipefish spawning is fractional, there were eggs in different stages of maturity in the ovaries (Fig. 1). In the period before spawning oocytes in phase of oocyte in the phase of primary follicle $\left\langle\mathrm{C} »\right.$, oocytes in the phase of initial accumulation of yolk and vacuolization $\left\langle\mathrm{D}_{1}-\mathrm{D}_{3}\right\rangle$, and oocyte in the phase of trophoplasmatic growth «E» with the transition to phase definitive size «F» (mature oocyte) were observed in the gonads of fish at the same time. 


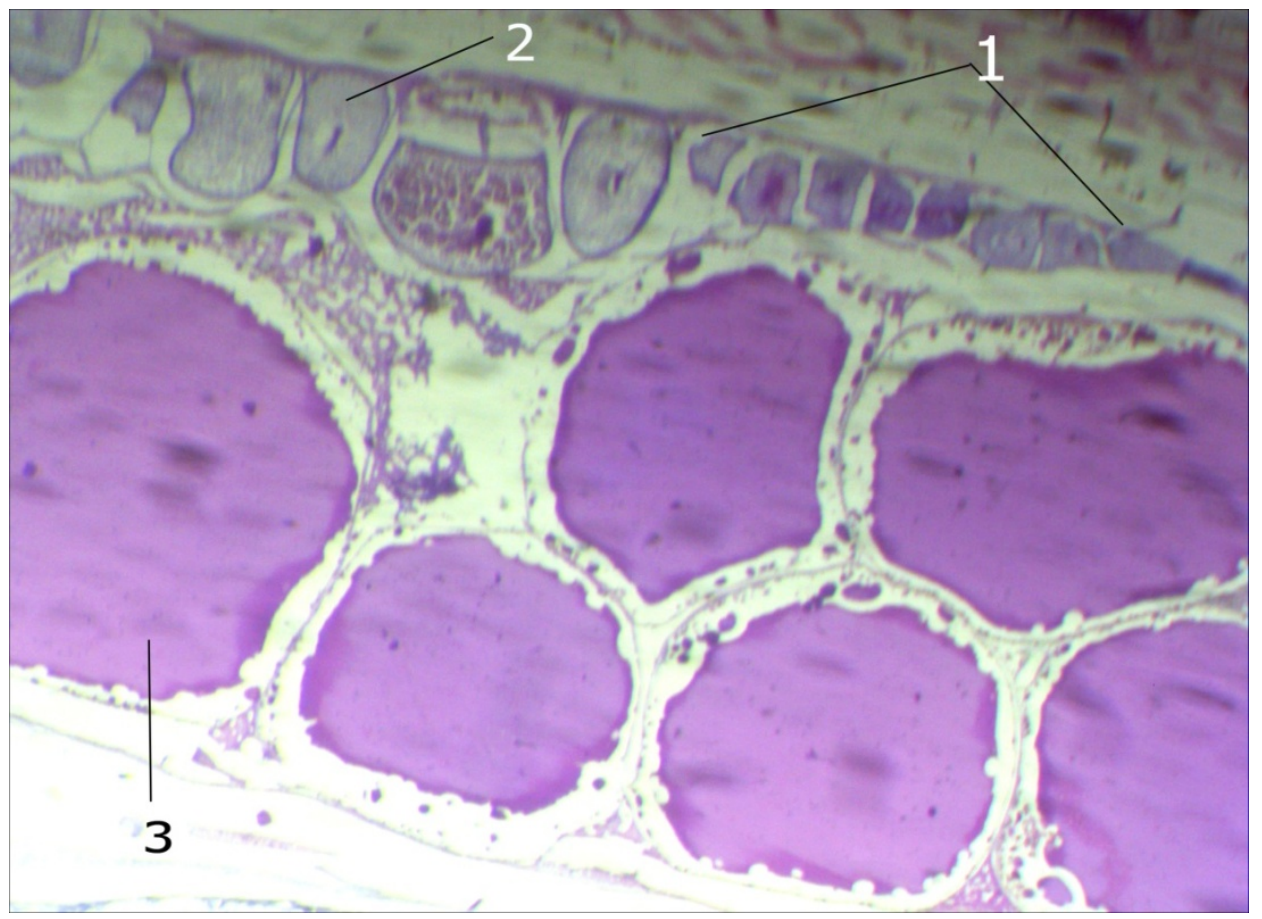

Figure 1. Microphorograph of hystological section of ovarie of pipefish: 1 - oocyte in the phase of primary follicle $« \mathrm{C} » ; 2$ - oocyte in the phase of vacuolation $\left\langle\mathrm{D}_{3} » ; 3\right.$ - oocyte in the phase of trophoplasmatic growth «E», beginning phase of mature follicle «F» (4x magnification).

Oocytes in the early stages of development, as it can be seen in micrographs, held peripheral position in the ovary (Fig. 1), while formed eggs were located in the center of gonads (Fig. 2). Ratio of oocytes in previtellogenesis period to oocytes in period of early and late vitellogenesis was approximately $1: 1$.

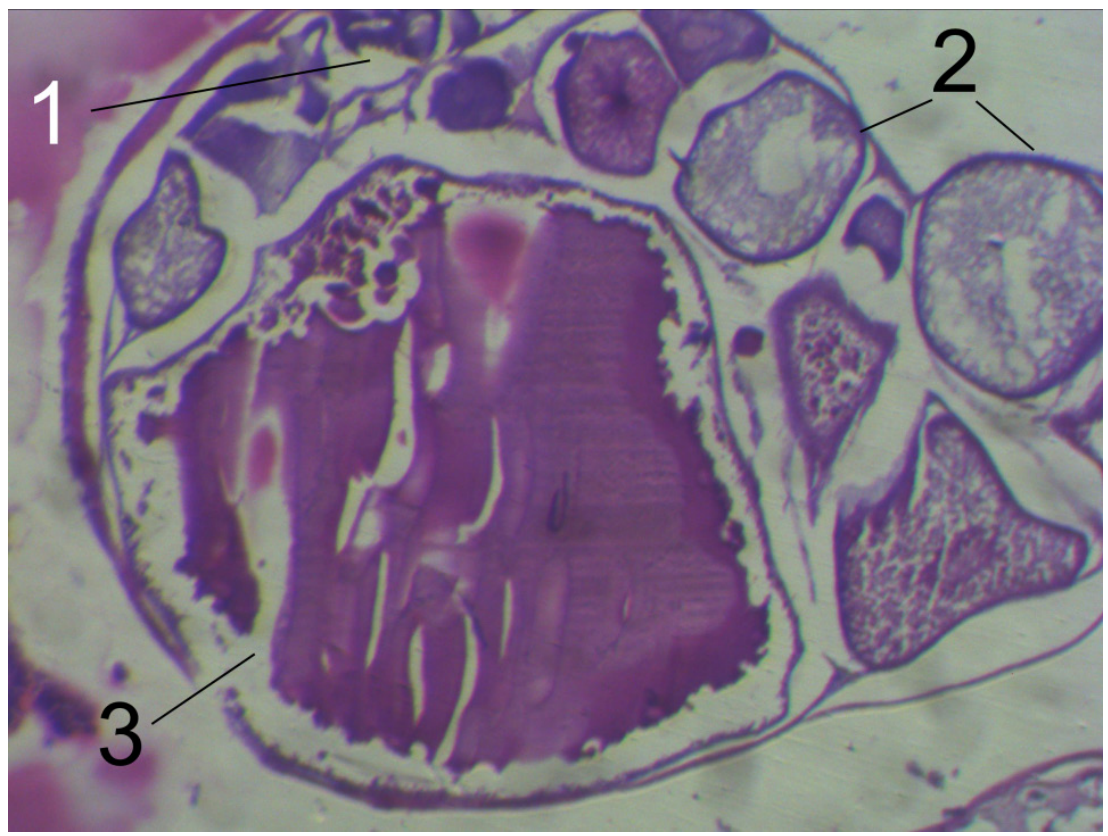

Figure 2. Microphorograph of hystological section of ovarie of pipefish: 1 - oocyte in the phase of primary follicle $« \mathrm{C} » ; 2$ - oocyte in the phase of vacuolation $« \mathrm{D}_{3} », 3$ - oocyte in the phase of trophoplasmatic growth «E», beginning phase of mature follicle «F» (6x magnification).

The analysis of histological sections of pipefish gonads has shown that the outer part of oocytes in vacuolization stage phase $\left\langle\mathrm{D}_{3}\right\rangle$ is filled by vacuoles; they occupied area of the cytoplasm up to the nucleus (Fig. 3). During this period, the egg had area of cross-section $0.49 \pm 0.002 \mathrm{~mm}^{2}$ and size of $0.11-0.58 \mathrm{~mm}$. 


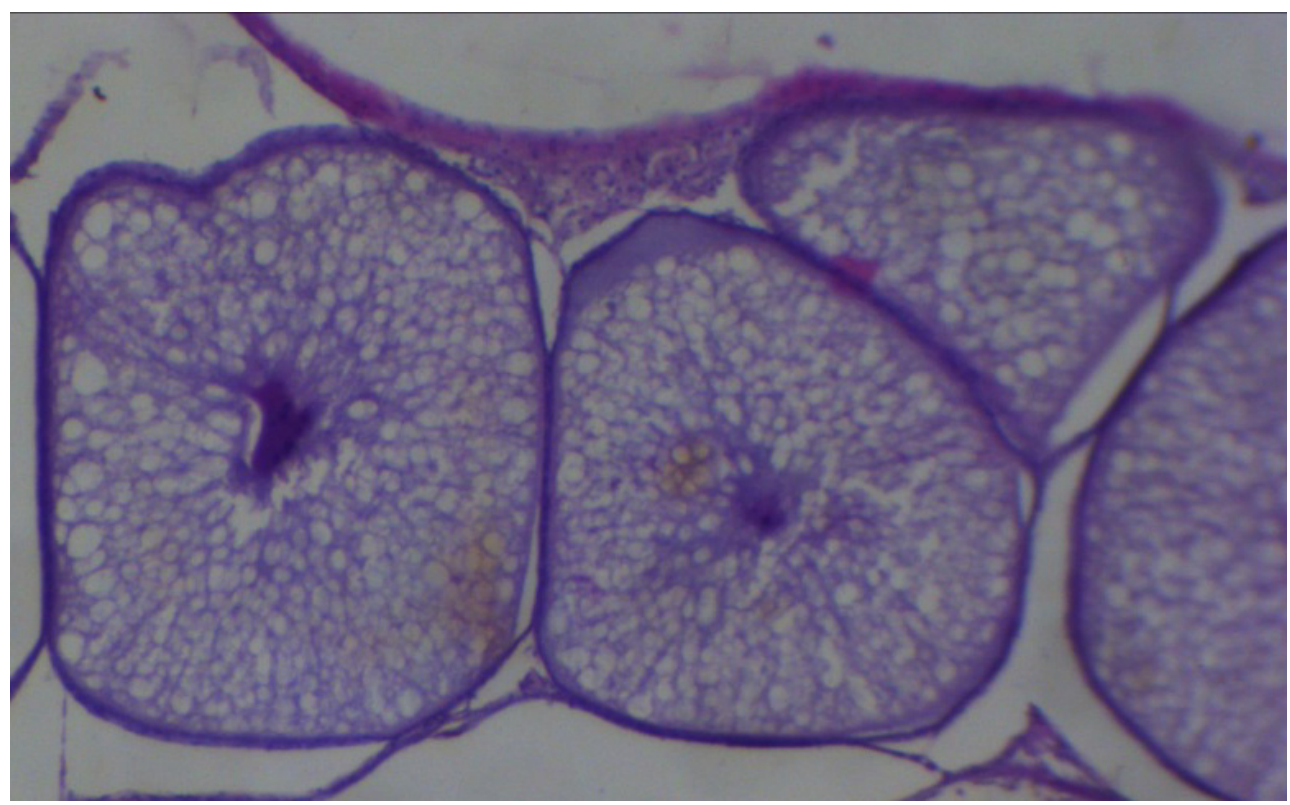

Figure 3. Pipefish oocytes in vacuolization stage phase $« \mathrm{D}_{3} »(8 \mathrm{x}$ magnification).

Mature eggs in late vitellogenesis period (phase «E») had area of cross-section $0.96 \mathrm{~mm}^{2}$ and large diameters of 0.91-1.48 mm (Table. 1). After the process of accumulation of yolk merger of its lumps into larger formation of yolk condensation was observed, so almost the entire area of oocyte looked homogenous and was dyed uniformly (Fig. 4). In this case oocytes of pipefish passed from phase $\left\langle\mathrm{E}_{3}\right\rangle$ to the phase of mature cells $\langle\mathrm{F}\rangle$ (so-called $\langle\mathrm{E}-\mathrm{F} »$ subphase) and reached a definitive size and were ready to ovulate.

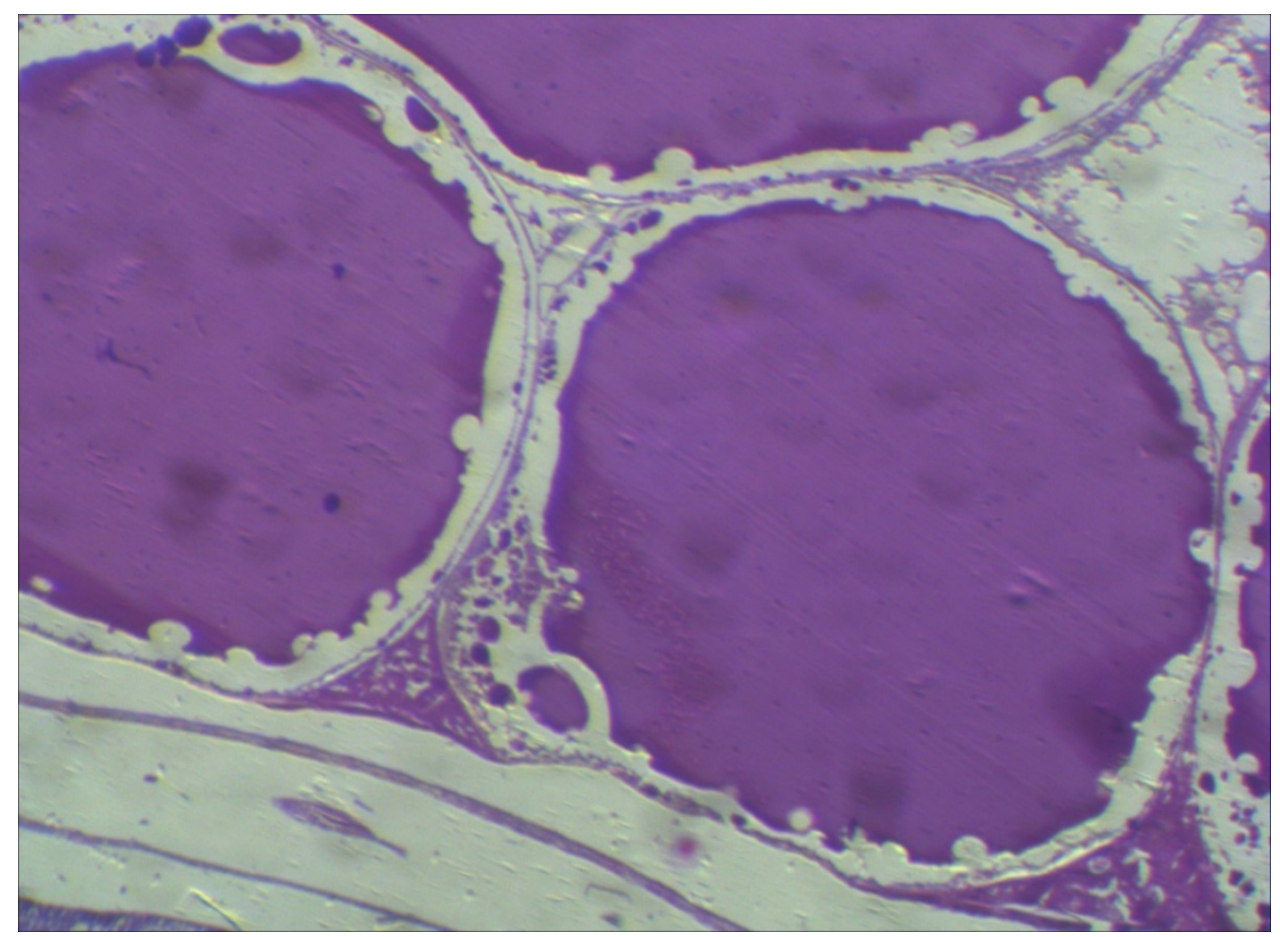

Figure 4. Mature oocytes of pipefish in late vitellogenesis period, the completion of phase «E»: homogenization of content of oocyte maturation (6x magnification).

During the maturation of pipefish eggs there was a significant thickening of eggs 'membrane. Thus, in the early vitellogenesis period cell membrane of pipefish eggs had an average thickness of $13.06 \mathrm{um}$, and in the further maturation of eggs in the late vitellogenesis period and completion of maturation before spawning (phase «E» and $\langle\mathrm{F}\rangle)$ membrane got thicker almost 6.5 times and reached the thickness of 85.85 um (Table. 1). This thickening of pipefish eggs membrane explains 
the biological features of the species breeding, as thick and gelatinous membrane ensures proper fixing egg in pipefish male`s brood chamber.

The size of the sample of eggs in early vitellogenesis period amounted to 139 units. The thickness of the membrane of oocytes ranged between 8.22 to $24.51 \mathrm{um}$, the average thickness of eggs' membrane during this period reached $13.06 \mathrm{um}$. Average diameter of oocytes in early vitellogenesis period was $229.54 \mathrm{um}$, the smallest diameter was $110.4 \mathrm{um}$, and the largest was 579.9 um.

The total number of measured eggs in late vitellogenesis period was 140 . The thickness of the membranes of these cells ranged from 36.38 um to 123.31 um with an average index of $85.85 \mathrm{um}$. The average diameter of researched cells was $1106.11 \mathrm{um}$, and it ranged from $905.2 \mathrm{um}$ to 1488.8 um.

Table 1. Sizes of pipefish eggs in early and late vitellogenesis period $(\mathrm{x} \pm \mathrm{SD})$.

\begin{tabular}{|c|c|c|c|}
\hline $\begin{array}{l}\text { Period / phase of } \\
\text { cell development }\end{array}$ & $\begin{array}{l}\text { Thickness of } \\
\text { membrane, um } \\
\underline{M \pm m} \\
\text { min-max }\end{array}$ & $\begin{array}{c}\text { Diameter of oocyte, } \\
\text { um } \\
\frac{\mathrm{M} \pm \mathrm{m}}{\min -\mathrm{max}}\end{array}$ & $\begin{array}{l}\text { Area of oocyte, } \\
\qquad \mathrm{mm}^{2} \\
\underline{\mathrm{M} \pm \mathrm{m}} \\
\operatorname{min-max}\end{array}$ \\
\hline $\begin{array}{c}\text { Early vitellogenesis } \\
\text { «D» phase, } \\
n=139\end{array}$ & $\frac{13.06 \pm 0.12}{8.22-24.51}$ & $\frac{229.54 \pm 6.46}{110.4-579.9}$ & $\frac{0.49 \pm 0.002}{0.11-0.58}$ \\
\hline $\begin{array}{c}\text { Late vitellogenesis } \\
\text { «E» phase, } \\
n=140\end{array}$ & $\frac{85.85 \pm 0.86}{36.38-123.31}$ & $\frac{1106.11 \pm 7.73}{905.2-1488.8}$ & $\frac{0.96 \pm 0.012}{0.64-1.74}$ \\
\hline
\end{tabular}

Note: $\mathrm{n}$ - number, $\mathrm{M} \pm \mathrm{m}$-average value and observational error, min-max - range of minimal and maximal values.

Research of pipefish reproduction has important theoretical and practical significance for resolving issues with the spread of this species and its adaptation to new conditions. An important aspect of the research on the reproductive features of pipefish is studying histological features of sexual products and phases of the gonads development of black-stripped pipefish under conditions of the Zaporizke Reservoir. Further research of the reproductive systems of pipefish should include biochemical and genetic research methods that will study the processes of adaptation of species to different living conditions and identify direction of microevolution processes.

\section{Discussion}

During all stages of the Zaporizke Reservoir being, fish fauna of the reservoir was significantly transforming. Current composition of the reservoir fish fauna includes 52 fish species intended to 14 families. During period from the Dnipro existence as a river to its flood control, number of fish species remained the same, but the composition of fish species has changed radically because distribution of new fish species. The fauna structure is considerably influenced by the complex of ecological factors that generated changes in ichtyocoenosis. Increase in number of species is associated with the various events. Firstly, after disappearance of the Dnipro Rapids and rise of water mineralization, it was began the self-colonizing process, resulted in transfer of southern species into the reservoir, such as Alosa pontica (Eichwald, 1838), Gasterosteus aculeatus (Linnaeus, 1758), S. abaster Risso, 1827, Aterina pontica (Eichwald, 1831), Clupeonella cultriventris (Normann, 1840) tadpole goby, Benthophiloides brauneri (Beling et Iljin, 1927).

Pipefish is found in a basin of the Zaporizke Reservoir in 1931, it swims into rivers, lakes and small reservoirs connected with it. This is nonmigratory, widespread, numerous species in coastal biocenoses of waters in Dnipro region. It is found throughout the coastal area of the reservoir and its tributaries, drainage channels. It lives both in the open water and in the thickets of higher aquatic vegetation. Species has extended its range and settled in small rivers of reservoir's basin such as Mokra Sura River, Samara River, Orel River. At the beginning of 2000, pipefish was not met in the 
Mokra Sura River, and in recent years pipefish is a typical species of coastal areas of this river. It has also reached closed aquatic ecosystems of Dnipro region such as flooded quarries, lakes and ponds. Prevalence of pipefish is caused by floods, the human factor and water birds that can carry aquatic vegetation with pipefish larvae and fries to other water bodies, where they adapt, breed and increase their number.

This species does not form large clusters, pipefish is found in groups of 10-15 individuals. They swim slowly through active movement of the pectoral fins and wave-like movement of dorsal fin. These fish are hardly noticeable on a on the background of aquatic vegetation because of their color.

The pipefish spawning in the basin of the Zaporizke Reservoir was not previously investigated. We have collected the material from different water bodies of Dnipro region and different parts of the Zaporizke Reservoir during 2013-2016. Specific differences between the timing of spawning and incubation of pipefish eggs in waters of Dnipro region were not observed.

Under conditions of the Zaporizke Reservoir pipefish spawns at a temperature of $18.0-22.0^{\circ} \mathrm{C}$ in the coastal area of the reservoir at a depth of 0.4 to $1.3 \mathrm{~m}$. Reproduction of pipefish in the basin of the reservoir begins at the second half of May and lasts until August, mass spawning occurs in June. Females with eggs as well as the males with filled brood chambers or formed embryos are observed in June.

In waters of Dnipro region breeding of black-stripped pipefish occurs in the intertidal zone among thickets of vegetation in shallow depths (typically $1 \mathrm{~m}$ ), usually in the same place where they live permanently. There were found females, which have had eggs with different diameters and males with eggs, free embryos and larvae with different sizes, indicating the fractional spawning. Earlier, fractional spawning of pipefish was supposed by M.S. Burnashev and others [9]. They observed that the female in one growing season is able to spawn 4-5 portions of eggs. Thus, we can confidently say that spawning of females is fractional; eggs are laid in several portions, the male receives eggs from several females. In early June, we caught males with not completely filled brood chambers but in the end of June all males had filled brood chambers.

Several authors note in their studies fluctuations in fertility of pipefish in a wide range. It is known that fish with length of $10.7-13.2 \mathrm{~cm}$ ( 3 ind.) has gonads weighting $0.15 \mathrm{~g}$ and the number of eggs ranges from 28 to 79 pcs. Their size is $1.0-3.0 \mathrm{~mm}$ [14]. In earlier studies it was observed that the fertility of pipefish is at the level of 75-85 eggs [15]. M.S. Burnashev and others [9] indicate in their research that the number of eggs in males chambers may reach 130 units. M.Y. Savchuk [16] notes that the maximum fertility of females 171-190 mm long equals to 178 (on average 95) eggs and the average fertility of pipefish in the Azov Sea is 89 eggs. Brood chambers of males 90-190 mm long contained 88 (32-190) eggs [9]. In our studies pipefish with a body length of 8.9 to $12.5 \mathrm{~cm}$ had gonads with weight of about $0.13 \mathrm{~g}$, and the number of eggs ranged from 26 to 68 . The maximum fertility had female $155 \mathrm{~mm}$ long and it reached 69 eggs. Size of eggs reached about $1.2 \pm 0.05 \mathrm{~mm}$. It is noted that an increase in body length and weight of individuals increases the fertility of females and the number of offspring that males are able to bear.

The eggs of pipefish have a considerable supply of nutrients and a large drop of fat, located on the periphery.

Like all Syngnathids, pipefish female lays eggs to the male`s brood chamber, which incubates the eggs and embryos. In brood chambers of researched males 120-149 $\mathrm{mm}$ in length there were averages of 54 (ranging from 41 to 66) eggs. The eggs were placed in a chamber in two and sometimes three longitudinal rows, confirming the results of research of Y.V. Movchan [9]. The eggs were tight to each other. When male receives eggs into brood chamber, its shutters are closed and grow, thus eggs are isolated from the external environment [17].

In brood chamber of male eggs are surrounded by a special gelatinous tissue permeated by a dense network of blood vessels that come here from the circulatory system of the male, which bring oxygen to the eggs. The development of eggs depends on the water temperature and lasts 24 to 32 days after fertilization. Males with formed embryos were caught in waters of Dnipro region in midJune. 
Number of free embryos in brood chambers of males ranged from 35 to 72 . After the embryonic development young pipefish is completely formed, has a dark brown color and looks like adults. Fries 1-1.5 mm long with fully formed paired and unpaired fins leave brood chambers. Fries leave brood chamber simultaneously by abrupt bending movements of the male's body. For some time they swim near a male and hide into his brood chamber and a couple of days later they leave the male.

\section{Conclusions}

1. Due to its ecological plasticity, euryhalinity and adaptation capabilities of reproductive system pipefish has expanded its range and increased the number in the basin of the Zaporizke Reservoir.

2. Under conditions of the Zaporizke Reservoir pipefish spawns at a temperature of 18.0$22.0^{\circ} \mathrm{C}$ in the littoral part at a depth of 0.4 to $1.3 \mathrm{~m}$. Reproduction of pipefish in the basin of reservoir begins in the second half of May and lasts until August, mass spawning occurs in June.

3. Pipefish with a body length from 9 to $12 \mathrm{~cm}$ had gonad weighting about $0.13 \mathrm{~g}$, and the number of eggs ranging from 26 to 65 . The female of $155 \mathrm{~mm}$ long had the maximum fertility that reached 69 eggs. Size of eggs reached about $1.2 \pm 0.05 \mathrm{~mm}$. Spawning is fractional, so eggs are laid in several portions; the male receives eggs from several females. The eggs of pipefish have a considerable supply of nutrients and a large drop of fat, which is located on the periphery.

4. In brood chamber of researched males 120-149 $\mathrm{mm}$ long there were about 54 (range from 41 to 66) eggs. Eggs were located by 2 and, sometimes 3 longitudinal rows Number of free embryos in brood chambers of males ranged from 35 to 72 . Fish fries with length of $1-1.5 \mathrm{~mm}$ with fully formed fins leave brood chambers.

5. Eggs in different stages of maturity were observed in the ovaries of researched fish: oocytes in the phase of primary follicle $« \mathrm{C} »$; oocytes in the phase of initial accumulation of yolk and vacuolization $\left\langle\mathrm{D}_{1}-\mathrm{D}_{3}\right\rangle$ and oocytes in the phase of trophoplasmatic growth «E», beginning phase of mature follicle $\langle F\rangle$. Oocytes in the early stages of development held peripheral position in the ovary, while formed eggs were located in the center of gonads. Ratio of oocytes in previtellogenesis period to oocytes in period of early and late vitellogenesis was approximately 1:1.

6. Outer part of oocytes in vacuolization stage phase $\left\langle\mathrm{D}_{3}\right\rangle$ is filled by vacuoles; they occupied area of the cytoplasm up to the nucleus. During this period, the egg had area of cross-section $0.49 \pm 0.002 \mathrm{~mm}^{2}$ and size of $0.11-0.58 \mathrm{~mm}$. Mature eggs in late vitellogenesis period (phase «E») had area of cross-section $0.96 \pm 0.012 \mathrm{~mm}^{2}$ and large sizes of $0.91-1.48 \mathrm{~mm}$ in diameter.

7. In the early vitellogenesis period cell membrane of pipefish eggs had an average thickness $13.06 \pm 0.12 \mathrm{um}$, and in the further maturation of eggs in the late vitellogenesis period and completion of maturation before spawning (phase «E» and «F») membrane got thicker almost 6.5 times and reached the thickness of $85.85 \pm 0.86 \mathrm{um}$. This thickening of pipefish eggs membrane explains the biological features of the species breeding, as thick and gelatinous membrane ensures proper fixing egg in pipefish male`s brood chamber.

\section{References}

[1] O. Fedonenko et al., Reproductive biology and quantity evaluation of the Black-striped pipefish Syngnathus abaster (Eichwald, 1831) in the Zaporozhian Reservoir, International Letters of Natural Sciences. 52 (2016) 54-59.

[2] C.E. Dawson, Syngnathidae, Fishes of the North-eastern Atlantic and the Mediterranean. 2 (1986) 628-639.

[3] D. S. Khrystenko, N.Ya. Rudyk-Leuska, G.O. Kotovska, Atlas adventyvnoyi ixtiofauny basejnu r. Dnipro [Atlas of alien fish fauna of the Dnipro river basin, Monograph.], Fitosociocentr, Kiev, Ukraine, 2012. (In Ukrainian). 
[4] N.A. Kiryukhina, Morphological variability in black-striped pipefish Syngnathus nigrolineatus in relation to its invasion into the Volga basin reservoirs, Russian Journal of Biological Invasions. 4(3) (2013) 149-155.

[5] L.S. Berg, Ryby presnyh vod SSSR I sopredel'nyh stran. [Fishes of fresh waters of the USSR and the neighboring countries], AN USSR, Moscow-Leningrad. Part. 3 (1949) 927-1382. (In Russian).

[6] R.H. Kuiter, Seahorses, pipefishes and their relatives. A Comprehensive Guide to Syngnathiformes, TMC Publishing, Chorleywood, UK, 2001.

[7] M. Kottelat, J. Freyhof, Handbook of European freshwater fishes, Publications Kottelat, Switzerland, 2007.

[8] D. Khrystenko, G. Kotovska, R. Novitskij, Length-weight relationships and morphological variability of black-striped pipefish Syngnathusabaster Risso, 1827 in the Dnieper River Basin, Turkish Journal of Fisheries and Aquatic Sciences. 15(3) (2015) 609-618.

[9] Yu.V. Movchan, Fauna Ukrainy. Ryby. T. 8. vyp. 3. [Fauna of Ukraine in 40 volumes. Vol. 8. Fishes. Part. 3], Naukova dumka, Kyiv, Ukraine, 1988. (In Russian)

[10] V.L. Bulakhov et al., Biolohichne riznomanittya Ukrayiny. Dnipropetrovska oblast. Kruhloroti (Cyclostomata). Ryby (Pisces) [Biological diversity of Ukraine. Dnipropetrovsk region. Cyclostomes (Cyclostomata). Fish (Pisces)], Dnipropetrovsk University Press, Dnipropetrovsk, Ukraine, 2008. (in Ukrainian)

[11] A.F. Koblitskaia, Opredelitel' molodi presnovodnykh ryb [Determinant of freshwater fish juvenile], Nauka Publ., Moscow, USSR, 1981. (In Russian)

[12] S. Mumford et al., Fish histology and histopathology, 4th Edition, US Fish \& Wildlife Service, West Virginia, 2007.

[13] E.V. Mikodina et al., Histology for ichthyologists: Experience and recommendations. VNYRO Publ., Moscow, Russia, 2009.

[14] K.A. Vinogradov, K.S. Tkacheva, O plodovitosti pribrezhnyh ryb Chernogo morja [About fertility of coastal fishes of Black Sea], Dokl. AN USSR. 65(3) (1949) 381-384. (In Russian)

[15] K.F. Kessler, Puteshestvie, s zoologicheskoju cel'ju, k severnomu beregu Chernogo morja i v Krym, v 1858 godu [Journey with the zoological purpose to the Black sea's north shore and the Crimea in 1858], Kiev, 1860. (in Russian)

[16] M.J. Savchuk, Rasprostranenie i nekotorye biologicheskie osobennosti iglovyh ryb (Syngnathidae) v Azovskom more [Distribution and some biological features of pipefishes (Syngnathidae) in the Azov sea], Hydrobiological Journal. 17(13) (1981) 42-50 (In Russian)

[17] Ş. Gürkan, M. Çulha, Regional and seasonal distributions of some Syngnathid species in the coastal waters of Sinop Peninsula (southern Black Sea-Turkey), Journal of FisheriesSciences.com. 2(3) (2008) 536-544. 